DIAZ OLVERA L., PLAT D., POCHET P. (2008), Household transport expenditure in SubSaharan African cities: measurement and analysis, Journal of Transport Geography, Vol. 16, nº 1 , pp. 1-13.

\title{
HOUSEHOLD TRANSPORT EXPENDITURE IN SUB-SAHARAN AFRICAN CITIES: MEASUREMENT AND ANALYSIS
}

Dr Lourdes Diaz-Olvera*, Dr Didier Plat, Dr Pascal Pochet

Laboratoire d'Économie des Transports

ENTPE-Université Lyon 2-CNRS

rue Maurice Audin - 69518 Vaulx-en-Velin Cedex - France

Fax : (33) 472047092

Diaz@entpe.fr

Plat@entpe.fr

Pochet@entpe.fr

(33) 472047244

(33) 472047047

(33) 472047741

* Corresponding author 
Abstract 3

1. Introduction 4

2. Literature review 5

2.1. Transport expenditure as estimated by expenditure and consumption surveys 5

2.2. Transport expenditure as estimated by household travel surveys 8

3. Influence of methodological factors in transport expenditure estimates 9

3.1. What type of transport expenditure data: factual or frequency-based? 9

3.2. Should expenditure or income be used to measure household wealth? 10

3.3. Ranking of households: the key role of the equivalence scale 11

4. The case studies: Niamey, Ouagadougou and Dar es Salaam 12

5. Share of transport expenditure according to household wealth 14

6. Concentration index for transport expenditure 16

7. Average transport expenditure per person 17

$\begin{array}{ll}\text { 8. Conclusion } & 20\end{array}$

$\begin{array}{ll}\text { References } & 22\end{array}$ 


\title{
HOUSEHOLD TRANSPORT EXPENDITURE IN SUB-SAHARAN AFRICAN CITIES: MEASUREMENT AND ANALYSIS
}

\begin{abstract}
In Sub-Saharan Africa the cost of transport faced by city dwellers, particularly the poor, tends to add to their travel and economic difficulties. Knowledge of the burden of transport expenditure in the household budget seems essential for passenger transport policy formulation in order to improve their travel conditions and social equity.

The literature revue and the three case studies (Dar es Salaam, Niamey, Ouagadougou) show that estimates of travel expenditure are partially conditioned by survey data collection methodologies and by the choice of equivalence scales used to compare the standard of living of households. According to consumption and expenditure survey data, the relative amount spent on transport increases as household expenditure rises. Conversely, the share of transport decreases as income rises when analysing travel survey data. The sensitivity to the equivalence scale is tested for several transport expenditure indicators: the share of travel expenditure by household budget quintile, the concentration indices for public and private household transport expenditure and the average monthly expenditure per person on public and private transport. Results also highlight the fact that transport is a major component of household expenditure, that there are considerable inequalities between households and that regular use of motorized transport is unaffordable for poor populations. These findings have implications for both improving expenditure data collection methodologies in the transport area and formulating pro-poor urban policies.
\end{abstract}

Key words: transport expenditure, urban transport, survey methodology, equivalence scale, poverty, Sub-Saharan Africa. 


\section{INTRODUCTION}

The high demographic growth that has prevailed in the large cities of Sub-Saharan Africa for several decades has resulted in unplanned urban sprawl, with poor facilities and poor accessibility particularly for those living in informal settlements in outlying districts. Low-income populations are usually concentrated in these settlements and travel out of the district is very frequently problematic.

Academic work has shown evidence of the close relation between wealth and private car ownership rates in developing countries (Button et al., 1993; Dargay, Gately 1999). In most Sub-Saharan Africa cities, rates of private motor vehicle ownership are low and have tended to fall even further since the 1980s because of a substantial drop in purchasing power among urban populations, as has been assessed in Abidjan (Godard, Teurnier, 1992) and in Nigeria (Akinlo, 1998). With regard to the bicycle, apart from the exceptional case of Ouagadougou, it does not represent an attractive alternative for the majority of people, due to the negative social representations associating bicycle use with poverty and rurality (Pochet, Cusset, 1998).

Whenever they need to leave their residential district, the vast majority of urban dwellers are therefore dependent on public transport or walking. As a result of the current organization of transport supply, which is highly dependent on the small-scale operators from the informal sector (minibus and/or shared taxis), fares are not subsidized and poor city dwellers carefully prioritize their transport needs and expenditure. They frequently only use public transport for their most essential trips (i.e. to go to work), and at the start of the month, or at those times money happens to be available (see Grieco et al., 1996, for the example of female petty traders in Accra). Otherwise, they must walk, sometimes long distances, in order to carry out activities in other districts (Behrens et al., 2004).

A number of studies all seem to agree about the high sensitivity of transport expenditure to the effects of economic crises and structural adjustment policies. In Chawama, a poor district of Lusaka, two-thirds of low income households reduced their transport expenditure after the implementation of the adjustment and stabilization program in the early 1990’s (World Bank, 1994). Likewise, in Yaoundé, between 1991 and 1993, almost $60 \%$ of the poor reduced their consumption of transport services as a response to the economic crisis (Ngassam, Roubaud, 1994); moreover the reduction in the consumption of transport services seems to have been even greater than the reduction in living standards.

However, daily travel is not amongst people's or planning agencies' most pressing concerns due to the fact that transport is a derived demand, by-product of consumer outof-home activity needs. Greater importance is given to direct demand problems such as access to livelihood activities, housing and land tenure, drinking water, schools and dispensaries (Garau, 1989; Jaglin, 1995; Kourguéni et al., 1993). It nevertheless remains the case that financing of travel tends to add to households' economic difficulties, especially for the poor, and transport-related difficulties can cancel out anticipated progress in other fields of social and economic development. From this perspective, it is essential to make daily travel easier and cheaper for the poor. This would enhance 
access to jobs and productivity at work. It would also improve the use of basic facilities and services and the maintenance of social networks and community-based solidarities, which are even more essential at times of economic crisis (Gannon and Liu, 1997; Marie, 1997).

In this context, knowledge of the cost of transport for urban households is essential to design urban policies which aim to improve the travel conditions for the poor and increase social equity with regard to daily travel. However, like other geographical regions, Sub-Saharan Africa cannot be considered at all as a sole and homogeneous space. Local characteristics generate variability in travel expenditure, across cities but also within the same city, and this variability should be taken into account in transport policy formulation.

Empirical data on transport expenditure across cities and across time do exist, but they are still partial and sometimes even contradictory, as will become apparent from our literature review (section 2). Travel cost findings are conditioned not only by the urban and transport context of each city but also by data collection methodologies used in consumption surveys and travel surveys, and by the choice of equivalence scales when comparing travel expenditure between households (section 3). Methodological factors may thus greatly influence estimates and the reliability of analyses from existing data could then be called into question. To guarantee reliability of findings, a more in-depth analysis of transport expenditure is therefore undertaken. Sensitivity tests parameterized by four equivalence scales (section 4) applied to data sets collected in two consumption surveys (Ouagadougou and Dar es Salaam) and one travel survey (Niamey) measure the impact of methodological factors with regard to three travel expenditure indicators: the share of transport expenditure in the household budget (section 5), the concentration index of household transport expenditure (section 6) and the average travel expenditure per person (section 7). The conclusion (section 8) makes a number of proposals for improving data collection methods and knowledge on household transport expenditure.

\section{LITERATURE REVIEW}

\subsection{Transport expenditure as estimated by expenditure and consumption surveys}

Table 1 sets out a number of estimates of the transport share of household expenditure in African cities. These figures are for various dates, and in some cases precede the devaluation of the CFA Franc in 1994. They exhibit a high degree of heterogeneity, not only between the cities, but also for a given city at different dates, or even the same date. For example, a comparison between the results obtained for the seven capital cities of the countries in the WAEMU (West African Economic and Monetary Union) where the same household expenditure survey was performed in 1996 shows considerable differences between them, with transport's share of expenditure doubling as one moves from Dakar or Lomé (8\%) to Ouagadougou (16\%). Furthermore, the ranking of transport expenditure amongst the main expenditure items varies significantly according to the city. While in all the seven cities the largest share of household budget is spent on food, transport expenditure comes second in Bamako, Cotonou and Niamey, third in Abidjan and Ouagadougou and only fourth in Dakar and Lome. 
Table 1: The share of total household expenditure allocated to transport, based on expenditure and consumption surveys

\begin{tabular}{|c|c|c|c|c|}
\hline City & Survey & Date & $\begin{array}{c}\text { \% spent on } \\
\text { transport }\end{array}$ & Source \\
\hline \multirow[t]{3}{*}{ Abidjan } & Enquête Budget-Consommation & 1979 & 8.5 & Direction de la Statistique, 1986 \\
\hline & Enquête Niveau de Vie & 1995 & 11.9 & INSD, 1999 \\
\hline & Enquête UemoA sur les Dépenses des Ménages & 1996 & 9.5 & INSD, 1999 \\
\hline \multirow[t]{3}{*}{ Bamako } & Enquête sur les Dépenses des Ménages Urbains & $1985-86$ & 15.1 & Sanogo, 1993 \\
\hline & Enquête Budget-Consommation & 1988-89 & 14.6 & INSD, 1999 \\
\hline & Enquête UEMOA sur les Dépenses des Ménages & 1996 & 11.2 & INSD, 1999 \\
\hline Conakry & $\begin{array}{l}\text { Enquête de Consommation auprès des Ménages à } \\
\text { Conakry }\end{array}$ & $1990-91$ & 9.2 & Arulpragasam, del Ninno, 1993 \\
\hline \multirow[t]{3}{*}{ Cotonou } & Enquête Budget-Consommation & 1986-87 & 10.2 & INSAE, 1994 \\
\hline & $\begin{array}{l}\text { Enquête Légère sur les Activités Economiques des } \\
\text { Ménages (ELAM } 5 \text { bis) }\end{array}$ & 1996 & 22.1 & INSD, 1999 \\
\hline & Enquête UEMOA sur les Dépenses des Ménages & 1996 & 9.8 & INSD, 1999 \\
\hline \multirow[t]{2}{*}{ Dakar } & Enquête Sénégalaise auprès des Ménages & 1994-95 & 6.8 & $\begin{array}{l}\text { Ministère de l'Economie des Finances } \\
\text { et du Plan, } 1997\end{array}$ \\
\hline & Enquête UEMOA sur les Dépenses des Ménages & 1996 & 8.2 & INSD, 1999 \\
\hline Dar es Salaam & Human Resources Development Survey & 1993 & 9.1 & Diaz Olvera et al., 1998 \\
\hline \multirow[t]{4}{*}{ Douala } & Enquête MAETUR & 1978 & 8.0 & Ngabmen, 1997 \\
\hline & Enquête Budget-Consommation & 1983-84 & 9.0 & Lynch, 1991 \\
\hline & Enquête Camerounaise auprès des Ménages & 1996 & 12.1 & $\begin{array}{l}\text { Ministère de l’Economie et des } \\
\text { Finances, } 2001\end{array}$ \\
\hline & Enquête Dépenses des Ménages & 2000 & 16.0 & Min. de l’Eco. et des Finances, 2001 \\
\hline Kampala & National Household Survey & $99-2000$ & 9 & Uganda Bureau of Statistics, 2001 \\
\hline \multirow[t]{3}{*}{ Kinshasa } & Enquête Consommation & 1969 & 4.4 & Houyoux et al., 1986 \\
\hline & Enquête Consommation & 1975 & 7.4 & Houyoux et al., 1986 \\
\hline & Enquête Budgets des Ménages & 1986 & 9.4 & Houyoux et al., 1986 \\
\hline \multirow[t]{2}{*}{ Lagos } & Consumer Expenditure Survey & $1985-86$ & 0.9 & Canagarajah et al., 1996 \\
\hline & Consumer Expenditure Survey & 1992-93 & 3.7 & Canagarajah et al., 1996 \\
\hline Libreville & Enquête Budget-Consommation & 1993-94 & 9.4 & Banque Mondiale, 1996 \\
\hline \multirow[t]{2}{*}{ Lomé } & Enquête Budget-Consommation & 1987 & 10.4 & INSD, 1999 \\
\hline & Enquête UEMOA sur les Dépenses des Ménages & 1996 & 8.3 & INSD, 1999 \\
\hline Mombasa & Welfare Monitoring Survey & 1997 & 4.5 & CBS, HRSSD, 2000a \\
\hline Nairobi & Welfare Monitoring Survey & 1997 & 7.6 & CBS, HRSSD, 2000a \\
\hline Ndjaména & Enquête Conditions de Vie des Ménages & 1990 & 6.8 & Rone, 1995 \\
\hline \multirow[t]{5}{*}{ Niamey } & Enquête Budgets Familiaux Africains & 1961-62 & 5.3 & Michaud, 1964 \\
\hline & $\begin{array}{l}\text { Enquête sur la Consommation de Produits Essentiels } \\
\text { Enquête Budget-Consommation }\end{array}$ & 1986-87 & 8.7 & $\begin{array}{l}\text { Direction de la Statistique et de } \\
\text { l'Informatique, } 1988\end{array}$ \\
\hline & Enquête Permanente de Conjoncture Economique et & 1989-90 & 15.2 & DSCN, 1994 \\
\hline & Sociale & 1995 & 13.4 & DSCN, 1997 \\
\hline & Enquête UEMOA sur les Dépenses des Ménages & 1996 & 11.8 & NSD, 1999 \\
\hline \multirow[t]{2}{*}{ Ouagadougou } & ESP & 1994-95 & 12.9 & INSD, 1999 \\
\hline & Enquête UEMOA sur les Dépenses des Ménages & 1996 & 15.6 & INSD, 1999 \\
\hline \multirow[t]{6}{*}{ Yaoundé } & Enquête MAETUR & 1978 & 6.1 & Ngabmen, 1997 \\
\hline & Enquête Budget-Consommation & 1983-84 & 11.0 & Lynch, 1991 \\
\hline & $\begin{array}{l}\text { Enquête Rapide sur la Consommation des Ménages à } \\
\text { Yaoundé }\end{array}$ & 1993 & 14.8 & Ngassam, Roubaud, 1994 \\
\hline & Enquête Consommation 1-2-3 & 1993 & 16.8 & DIAL, DSCN, 1993 \\
\hline & Enquête Camerounaise auprès des Ménages & 1996 & 13.8 & $\begin{array}{l}\text { Ministère de l’Economie et des } \\
\text { Finances, } 2001\end{array}$ \\
\hline & Enquête Dépenses des Ménages & 2000 & 18.3 & $\begin{array}{l}\text { Ministère de l'Economie et des } \\
\text { Finances, } 2001\end{array}$ \\
\hline
\end{tabular}


The difficulty in obtaining convergent estimates is explained by factors of two types. The first relates to the specific features of each city, such as the size, the level of wealth, the characteristics of the passenger transport system, demographic trends, socio-cultural particularities, and the regulatory environment for housing ownership and land tenure. For example, the dominant position of private motorized transport (cars and particularly motorized two-wheelers) in Ouagadougou where public transport has been starved of resources, very probably explains why transport accounts for such a high proportion of household expenditure there. The second type of factor concerns the use of different methodologies which are not always precisely stated when the aggregated results are presented. Thus, in the published findings on transport expenditure for Yaoundé, communications is considered as part of the transport item; the figures for Nairobi and Mombassa focus on out-of-pocket transport costs and do not include vehicle purchase costs.

If we eliminate extreme values, it emerges from the expenditure and consumption survey data that households devote between $8 \%$ and $15 \%$ of their total expenditure to transport ${ }^{1}$. This percentage generally increases when household wealth increases, whether this wealth is estimated by distinguishing between poor and "non-poor" households (Table 2) or on the basis of total expenditure quartiles (Table 3). For a selected city, the difference in transport expenditure between household groups is nevertheless very variable. For instance, it is small in the case of Nairobi and considerably greater in urban Niger or in Yaoundé. Exceptions to the trend of increasing share of transport expenditure with increasing household wealth are rare, e.g. PortGentil or Abidjan in the mid-1980's, where the share of overall transport expenditure is $11.1 \%$ for the very poor households, $8.2 \%$ for the poor households and $12.0 \%$ for the non-poor households (Grootaert, 1993).

Table 2: The share of total household expenditure allocated to transport by poor and non-poor households (\%)

\begin{tabular}{lcc}
\hline & Poor & Non-poor \\
\hline Niger, urban areas, 1989/90 (World Bank, 1996b) & 4.2 & 16.1 \\
Yaoundé, 1993 (Ngassam, Roubaud, 1994) & 9.6 & 16.3 \\
Nairobi, 1997 (CBS, HRSSD, 2000b) & 6.3 & 7.8 \\
\hline
\end{tabular}

Table 3: The share of total household expenditure allocated to transport, according to household expenditure quartile (\%)

\begin{tabular}{lcccc}
\hline & $\begin{array}{c}\text { 1st } \\
\text { (top) } \\
\text { quartile }\end{array}$ & $\begin{array}{c}\text { 2nd } \\
\text { quartile }\end{array}$ & $\begin{array}{c}\text { 3rd } \\
\text { quartile }\end{array}$ & $\begin{array}{c}\text { 4th } \\
\text { (bottom) } \\
\text { quartile }\end{array}$ \\
\hline Libreville, 1993/94 (World Bank, 1996) & 7.3 & 7.8 & 9.1 & 11.3 \\
Port-Gentil, 1993/94 (World Bank, 1996) & 5.2 & 6.2 & 14.4 & 10.6 \\
Yaoundé, 1993 (DIAL, DSCN, 1993) & 9.9 & 10.1 & 15.6 & 22.8 \\
\hline
\end{tabular}

\footnotetext{
${ }^{1}$ For the purposes of comparison, housing, including electricity and water, accounts for between $15 \%$ and $20 \%$ of household expenditure in Africa according to Arnaud (1998), and between 15\% and 24\% according to the WAEMU surveys (INSD, 1999).
} 
However, whether we consider the level of expenditure or the way this changes as a function of the economic affluence of households, these results differ from those obtained from travel survey data.

\subsection{Transport expenditure as estimated by household travel surveys}

The expenditure data collected by travel surveys relates exclusively to transport, and these surveys attempt to relate it to household income. Available data are sparse and usually less recent than that provided by consumption surveys. According to the surveys conducted by the Transport and Road Research Laboratory in the 1980's (Maunder, Fouracre, 1987), the households in the Nigerian city of Jos spent $13 \%$ of their income on transport and those in Dar es Salaam spent 16\%. In Abidjan, at the end of the 1980's, public transport expenditure was estimated at $9 \%$ of average income and 13\% of medium income, but the figure for poor households was almost 20\% (Godard, Teurnier, 1992). In Ouagadougou, transport accounted for 20\% of household income in 1992 (Diaz Olvera et al., 1999). A 1996 survey of about 100 poor members of the working population of Dakar shows that 55\% spent more than $10 \%$ of their personal income on work-related travel, and three-quarters spent less than 20\% (Godard et al., 1996). However, these last figures are only minimum values to which the expenditure for non work-related trips must be added. In 2003, poor households in Conakry spent $19 \%$ of their income on urban travel and the non-poor 12\% (Sitrass, 2004a). For Douala, these figures were $23 \%$ and $16 \%$, respectively, in the same year (Sitrass, 2004b).

Measured on the basis of household income, the share of transport generally decreases as income rises. In Accra, although this percentage increases considerably when one moves from the first income class, the poorest, to the second (from 14\% to 24\%), it falls even more sharply in the third class and then continues to decline to reach $4 \%$ for the fifth and wealthiest class (Kwakye et al., 1997). In Ouagadougou, transport accounts for $25 \%$ of income for households in the bottom quintile and decreases to $18 \%$ for the top quintile (Diaz Olvera et al., 1999). The findings of other surveys conducted in the 1980s (Kranton, 1991) are more varied, i.e. while a similar decrease to that in Ouagadougou is observed in Nairobi and Casablanca, in Dakar the share of transport is quite stable between household groups and in Abidjan it is higher among affluent households.

Generally speaking, there is agreement in the specialized literature on transport in developing countries that the share of transport consumption decreases as income rises. For instance, Osula (1999) has observed this trend on the basis of work carried out by a number of researchers in Nigeria in the 1970s and 1980s and also referring to studies of Jamaica, Malaysia and India. More recently, Vasconcellos (2001) has described the same tendency based on several case studies from Latin America.

Thus, findings from household travel surveys data show that transport accounts for around $15 \%-20 \%$ of household income, which is higher than the estimate from consumption surveys. Moreover, travel surveys indicate that poor households spend a greater share of their income on transport than others. These contradictory results 
between data from consumption surveys and travel surveys are partly explained by differences in data collection and processing methodologies.

\section{INFLUENCE OF METHODOLOGICAL FACTORS IN TRANSPORT EXPENDITURE ESTIMATES}

\subsection{What type of transport expenditure data: factual or frequency-based?}

The major difference between on the one hand expenditure and consumption surveys and on the other travel surveys lies in distinct approaches to collect transport expenditure data. Consumption surveys essentially rely on the collection of factual data and are "concerned with facts, that is to say the number of times a given event takes place during a given period"2 (Blaizeau, Dubois, 1989: 138). Such data can either be collected on a daily basis (travel diaries), or retrospectively (recall diaries). On the other hand, travel surveys generally collect frequency-based data which "attempt to reveal a habit, postulates the existence of a norm based on a degree of regularity in the occurrence of the events in question"3 (Blaizeau, Dubois, 1989: 138). The respondent is therefore asked to estimate the amount he/she spends (in an average week, month or even year) on public transport and on the personal use of any available household vehicles (for the main consumption items e.g. fuel, maintenance and repair, insurance and road tax, and occasionally vehicle purchase).

The measurements produced by the two methods of data collection diverge, as witnessed by the 1996 consumption survey conducted in the seven member countries of the WAEMU (Blaizeau, 1999). The survey protocol specified that data should be collected for a few items of expenditure using both procedures. The outcome was that for urban travel expenditure, the frequency-based approach led to the overestimation of most repeated and frequent expenditure items (fuel and public transport) and the underestimation of items where more random payments were involved (vehicle maintenance and repair).

To the best of the authors' knowledge, a similar work concerning the comparison of data collection methodologies in household travel surveys has never been undertaken. However, the cross-comparison of data from the 1996 Niamey travel survey also suggests that the frequency-based approach can lead to a slight overestimation of transport expenditure. Weekly public transport expenditure stated by respondents was compared on the one hand with the travel the day before the interview and on the other with the out-of-home activities undertaken during the last seven days before the interview. These comparisons revealed that expenditure related to travel practices, such as the number of trips in public transport, can be implicitly overestimated by the respondent. Given that until now transport expenditure has not been retained as a key issue in most household travel surveys, there are usually no safeguards to limit this bias,

\footnotetext{
2 “s’intéresse aux faits, c’est-à-dire aux réalisations d’un événement donné sur une période donnée.”

3 “cherche à révéler une habitude, postule l’existence d’une norme basée sur une certaine régularité dans la réalisation des événements considérés.”
} 
such as detailed data on public transport use and the corresponding expenditure or information on the main household expenditure items (food, housing, clothing, etc.).

Conversely, some exceptional items of consumption are automatically underestimated when factual data collection is used ${ }^{4}$. The expenditure of individuals who use motorized modes episodically or rarely will statistically be less likely to occur during the survey period the shorter this is. In a expenditure or consumption survey there is a risk that some trips, and therefore the expenditure associated with them, will be omitted. It is known from field experience in travel surveys how difficult it is to collect information from individuals about all trips undertaken the day before if data collection does not follow time chronology strictly. Furthermore, in consumption surveys, one of the adults in the household, who is considered to be the best informed about the consumption and expenditure of the entire domestic unit is generally assigned as the spokesperson (Deaton, Grosh, 2001). However, the spokesperson is not always aware of all the trips made by household members or what expenditure is incurred, given that in Sub-Saharan Africa it is rare for incomes to be pooled in their entirety in the household budget. This applies in particular when households consist of several adult income-earners who can take in charge their own personal expenses, such as out-of-home meals, clothing, public transport or vehicle fuel.

Lastly, is must be mentioned that content of transport expenditure differs given that exactly the same travel expenditure items are not measured in the two types of surveys. While consumption surveys are concerned with expenditure on all types of transport, including non-urban travel, travel surveys focus on urban trips.

\subsection{Should expenditure or income be used to measure household wealth?}

The second major methodological difference between the two types of survey involves the reference point against which transport expenditure is compared - either total household expenditure or total household income can be used. Whether they wish to investigate the wealth of individuals or identify inequalities, economists generally prefer to use total expenditure rather than income, for reasons which are both theoretical and practical (with regard to countries of the South, see, for example, Muller, 1997; Deaton, Zaidi, 1999; Lancaster et al., 1999). Without attempting to give the full account of this topic, we can outline the following principles:

a. collection of household income is problematic because the incomes may come from a number of sources and involve episodic earnings which are difficult for the respondent to assess, as is very often the case for workers from the informal sector. Furthermore, questions about income are not always welcomed by respondents, which means that non-responses and underestimates are more frequent.

b. wealth is measured by the consumption of goods rather than by the possession of money;

\footnotetext{
4 This underestimation is not restricted to countries of the South but seems inherent to this type of data collection; it is also mentioned in the technical documents of the French Family Budget Survey (INSEE, 1997).
} 
c. the earnings of the majority of working populations fluctuate over a very short period of time, frequently from one day to the other. In contrast, consumption of most products is relatively more stable over time even though there is a seasonal dimension, such as religious festivals, and occasional expenditure, as for family funerals. “... observing consumption over a relatively short period, even a week or two, will tell us a great deal more about annual - or even longer period - living standards than will a similar observation on income.” (Deaton, Zaidi, 1999: 14).

Expenditure and consumption surveys are not spared from accuracy difficulties related to recalling, like other surveys, particularly if data collection concerns long periods or information too far back in time. However, a number of safeguards exist given that the definition of total expenditure and data collection protocols are precisely stated whereas definition and procedures for income data collection are more varied. For example, the household income is usually estimated by the sum of all the individuals' incomes, which are collected by interviewing separately each individual. But, as mentioned above, individuals usually keep a proportion of their earnings for themselves in order to retain some economic independence as in Abidjan (Leimdorfer, 1997; Yapi-Diahou, 2000), Brazzaville (de Suremain, 1997), Ouagadougou (Kinda, 1987) and Kinshasa (Houyoux et al., 1986).

Even though the notion of household income in most travel surveys still remains varied (Osula, Adebisi, 2001), there are nevertheless significant benefits from the availability of information on personal incomes with regard to transport-related issues. In particular, former research has revealed that access to motorized transport is highly dependent on the possibilities of the individual earning an income, either at the present time (workers) or in the long term (students). The young and the unemployed are therefore at a disadvantage (Diaz Olvera et al., 1999). When transport expenditure and consumption are examined solely at household level there is a risk that inequalities between individuals, particularly between men and women, may be overlooked (Case, Deaton, 2002; Mattila-Wiro, 1999).

\subsection{Ranking of households: the key role of the equivalence scale}

Finally, in order to study inequalities between households, it is necessary to compare the position of households whose size and demographic structure differs. The standard of living provided by a given budget (expenditure or income) will be different for a oneperson household and a larger household, even if in the latter economies of scale apply in the case of some goods. The use of an equivalence scale allows comparisons between households with different demographic characteristics by converting the number of persons in a household into a number of consumption units, each with identical needs.

Many different scales can be devised, but much empirical research demonstrates the considerable variations between the estimates when different scales are applied to a particular country at a particular date. Consequently, a great deal of controversy surrounds the choice of such scales (Lechêne, 1993). These variations are troublesome as they affect the position of each household within the distribution as a whole. The make-up of groups of households (the poorest quintile for example) can therefore change quite markedly according to which equivalence scale is used (Quisumbing et al., 
1995; Deaton, 1997; Duclos, Mercader-Prats, 1999). The calculation of per capita income, for example, is based on an equivalence scale which assumes that all individuals have identical needs (each individual is given the same weighting) and makes no allowance for economies of scale. It therefore tends to exaggerate child poverty, while the indicator constructed on the basis of total income or total expenditure underestimates it (Deaton, Paxson, 1997).

The lack of consensus in favor of a particular scale provides an incentive for performing sensitivity tests of statistical data to various equivalence scales (Muller, 1997; Ekström, 1998; Deaton, Zaidi, 1999).

Two main lessons can be drawn from the foregoing discussion. The first one is that, because of the likelihood that travel expenditure is overestimated by travel surveys and underestimated by consumption surveys, the range of household travel expenditure in Sub-Saharan African cities would be $8 \%$ to $20 \%$ of total household budget. The second one is that methodological factors concerning data collection and data processing greatly influence estimates and there is no way of measuring biases produced by these factors with the current state of knowledge.

Therefore, the reliability of empirical data analyses needs to be assessed. To enhance knowledge on household and individual transport expenditure and to guarantee reliability of findings, a more in-depth analysis of three case studies is undertaken. The analysis takes into account the type of empirical data and sensitivity tests of three indicators of transport expenditure to four equivalence scales are conducted.

\section{THE CASE STUDIES: NIAMEY, OUAGADOUGOU AND DAR ES SALAAM}

Two consumption surveys and one travel survey were selected for the case studies. Table 4 sets out the main characteristics of the statistical data. At the time of the surveys, the contexts of the three selected cities were quite different from several perspectives, including the passenger transport sector. Niamey and Ouagadougou were small-sized cities compared to Dar es Salaam (approximately 600 000, 700000 and 1500000 inhabitants, respectively). The transport system in Ouagadougou was dominated by two-wheelers, mostly motorized. In Niamey and particularly in Dar es Salaam, private vehicle ownership was very low. In all three cities, a state-owned company operated under great technical and financial difficulties and unregulated operators dominated the public transport market.

Table 4: The three case studies

\begin{tabular}{lcccc}
\hline & Date & Survey type & $\begin{array}{c}\text { Number of surveyed } \\
\text { households }\end{array}$ & $\begin{array}{c}\text { Statistically } \\
\text { representative }\end{array}$ \\
\hline Niamey (Niger) & 1996 & Travel & $757^{*}$ & Yes \\
Ouagadougou (Burkina Faso) & 1996 & Consumption & 1008 & Yes \\
Dar es Salaam (Tanzania) & 1993 & Consumption & 1128 & Yes \\
\hline
\end{tabular}

*consisting of 2732 persons aged 14 years and over, from which the following information was collected individually: income, expenditure on personal vehicle use and public urban transport and all trips made the day before the interview. 
The level of transport expenditure was also quite different between the three cities. In Niamey, transport expenditure accounted for $18.4 \%$ of average income, compared with $15.6 \%$ of average expenditure in Ouagadougou and 9.1\% in Dar es Salaam. These estimates are consistent with the ranges described in the literature for similar types of survey.

However, these average values should not conceal the fact that in all three cities transport expenditure was very unevenly distributed amongst households, as illustrated by the dispersion of expenditure when households are ranked on the basis of increasing transport expenditure, without reference to their wealth (Table 5). For instance, considering total transport expenditure in Niamey, 50\% of households which spent the least accounted for only $13 \%$ of total transport expenditure. The concentration of expenditure was even more marked in the case of personal transport modes, particularly cars, for which $10 \%$ of households accounted for almost $80 \%$ of expenditure. Similar orders of magnitude were replicated in Ouagadougou and Dar es Salaam, nevertheless with slight differences which can be explained by the specific features of public and personal transport supply mentioned above.

Table 5: Percentages of households with the lowest expenditure for various items of transport expenditure*

\begin{tabular}{lllll} 
& $10 \%$ & $50 \%$ & $75 \%$ & $90 \%$ \\
\hline Niamey & & & & \\
Total transport expenditure & 0.1 & 13.2 & 34.2 & 59.8 \\
$\quad$ Expenditure on public transport & 0.0 & 12.3 & 38.2 & 65.3 \\
$\quad$ Expenditure on personal modes & 0.0 & 0.0 & 8.3 & 37.7 \\
$\quad$ Expenditure on cars & 0.0 & 0.0 & 0.0 & 18.2 \\
$\quad$ Expenditure on motorized two-wheelers & 0.0 & 0.0 & 0.0 & 37.3 \\
Ouagadougou & & & & \\
Total transport expenditure & 0.0 & 4.0 & 23.7 & 48.6 \\
$\quad$ Expenditure on public transport & 0.0 & 0.0 & 0.0 & 9.3 \\
$\quad$ Expenditure on personal modes & 0.0 & 2.7 & 21.7 & 47.1 \\
Dar es Salaam & & & & \\
Total transport expenditure & 0.0 & 8.0 & 23.6 & 41.9 \\
$\quad$ Expenditure on public transport & 0.0 & 10.6 & 32.4 & 57.0 \\
$\quad$ Expenditure on personal modes & 0.0 & 0.0 & 0.0 & 0.0 \\
\hline
\end{tabular}

* The households have been ranked according to their expenditure on each item of expenditure. Thus, in Niamey, the $75 \%$ of households who spend the least on personal modes account for $8.3 \%$ of total expenditure on these modes, while the $75 \%$ of households who spend the least on the car, spend nothing on car travel.

As discussed previously, the choice of the equivalence scale is essential for ranking households according to their wealth. Some of the usual equivalence scales take the form $(A+\alpha K)^{\beta}$ (Deaton, Paxson, 1997) where $\mathrm{A}$ is the number of adults (individuals aged 14 and over) and $\mathrm{K}$ is the number of children. $\alpha$ represents the relative cost of a child compared with an adult: the nearer this is to one, the greater the cost of the child. $\beta$ measures the elasticity of total expenditure to household size: the nearer this is to 1 , the smaller the economies of scale. The number of consumption units therefore varies between 1 (when $\beta=0$ ) and the size of the household (when $\alpha=\beta=1$ ). The wealth 
indicator which is evaluated, e.g. income per consumption unit, varies at a given time between the total income of the household and the per capita income.

Four scales that give contrasting results were selected from a set of 15 equivalence scales (Diaz Olvera et al., 2001): total household monetary resources ( $\beta=0$ ), per capita household monetary resources ( $\alpha=\beta=1$ ), and two intermediate measures between the two extremes $(\alpha / \beta): 0.50 / 0.75$ and $0.75 / 0.50$, for which the weighting given to transport expenditure for the first quintile, the poorest, differs considerably.

\section{SHARE OF TRANSPORT EXPENDITURE ACCORDING TO HOUSEHOLD WEALTH}

Figure 1 shows, for the three case studies, the share of transport expenditure by income or expenditure quintile estimated for the four selected equivalence scales. While in both Ouagadougou and Dar es Salaam, the choice of an equivalence scale slightly changes the estimated share of travel expenditure or the trends for change, without altering the direction of the change, in Niamey the incidence of the equivalence scale is more significant. In this case, first, the share of transport varies from $22 \%$ to $32 \%$ for the first income quintile, the poorest, depending on the equivalence scale and second, the scale based on total income changes the order between two successive quintiles (25\% for the second quintile compared with $22 \%$ for the first). For Ouagadougou, the choice of the equivalence scale has very little incidence in the percentage of transport expenditure whatever the expenditure quintile; the greatest difference appears for the last quintile, the wealthiest, for which transport expenditure varies between 12\% (total expenditure scale) and 15\% (per capita expenditure scale). For Dar es Salaam, the trend of the equivalence scales is not as clear-cut as that of Ouagadougou but differences in the percentage of transport expenditure are still small (the largest are observed for the second and third quintiles) and there is no change in the order of quintiles.

Figure 1 also exhibits the major difference in findings due to the data source. According to the travel survey data, relative amount spent on transport decreases continuously as household wealth rises, irrespective of the equivalence scale, with only one exception (total income scale). Conversely, according to the expenditure survey data, the proportion of household budget that is spent on transport increases as the economic position of households improves. Analyzed separately, both data provide consistent results and the use of different equivalence scales generally produces the same relative position for transport expenditure in the different quintiles. But when results are compared between types of survey, the contradiction highlighted in section 3 becomes once more apparent. 
Figure 1: Sensitivity test of share of transport expenditure according to four equivalence scales

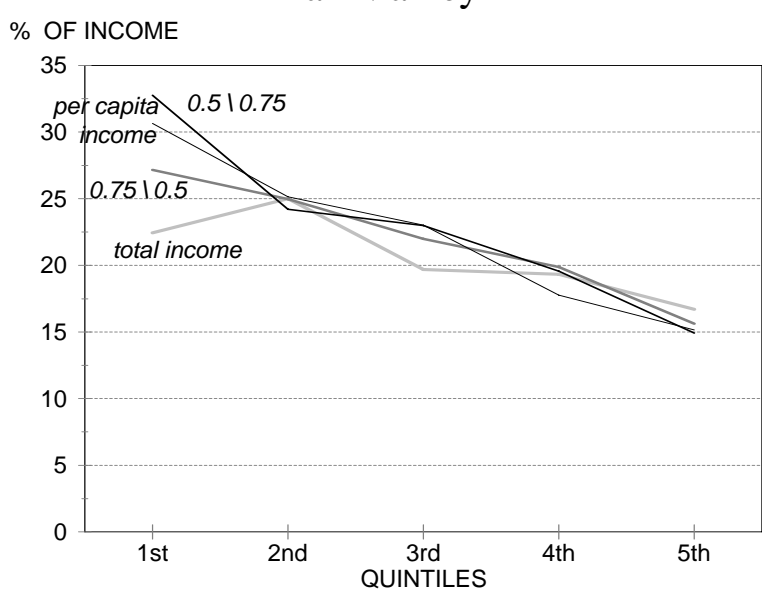

b- Ouagadougou

$\%$ OF TOTAL EXPENDITURE

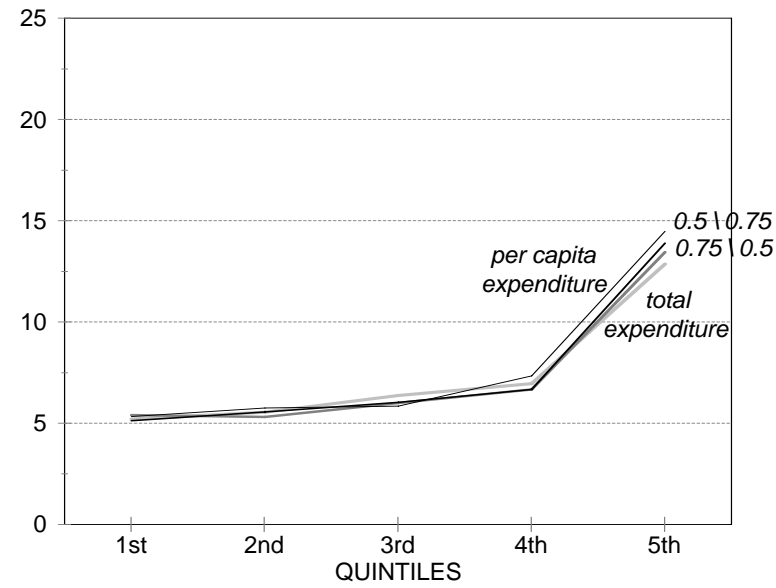

C- Dar es Salaam

$\%$ OF TOTAL EXPENDITURE

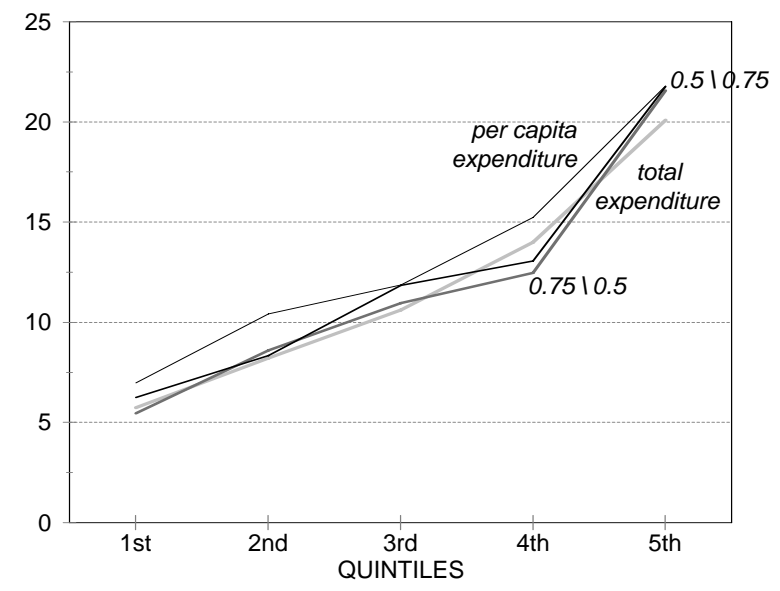


Transport expenditure in Niamey concerns only urban travel in public and private modes (without vehicle purchase for the latter). If the same type of expenditure is considered in Dar es Salaam and Ouagadougou, we find the same variations between quintiles seen above. For instance, if we classify households on the basis of their per capita budget, as one moves from the first to the last quintile, expenditure fluctuates between $5.3 \%$ to $11.6 \%$ of total expenditure in Dar es Salaam and between $4.8 \%$ to $12.4 \%$ in Ouagadougou. In order to make the data for the three cities more consistent, in what follows we shall consider only urban travel expenditure generated by public transport and personal modes.

\section{CONCENTRATION INDEX FOR TRANSPORT EXPENDITURE}

The concentration indices can be used to compare transport expenditure inequalities between households (Table 6). The concentration index is obtained by doubling the area between the expenditure concentration curve obtained if households are sorted by increasing income (or expenditure) and the line of equal distribution. It takes on a value between -1 and 1 . The higher it is, the more unequal the distribution of expenditure according to income (or expenditure). The comparison of concentration indices according to the equivalence scale reveal that they vary if one equivalence scale is used instead of another. However, the trend of variations between scales is the same, whatever the expenditure item and whatever the type of data set. In all three cities, the greater the size elasticity (and therefore the smaller the economies of scale), the lower the concentration indices and the inequalities amongst households are.

Table 6: Sensitivity of concentration indices for transport expenditure to equivalence scales

\begin{tabular}{|c|c|c|c|c|}
\hline & \multicolumn{4}{|c|}{ Equivalence scale } \\
\hline & $\begin{array}{c}\text { Total } \\
\text { income or } \\
\text { expenditure }\end{array}$ & $\begin{array}{c}\text { Scale } \\
0.75 / 0.50\end{array}$ & $\begin{array}{c}\text { Scale } \\
0.50 / 0.75\end{array}$ & $\begin{array}{l}\text { Per capita } \\
\text { income or } \\
\text { expenditure }\end{array}$ \\
\hline \multicolumn{5}{|l|}{ Niamey } \\
\hline Total transport expenditure & 0.44 & 0.39 & 0.35 & 0.30 \\
\hline Expenditure on public transport & 0.23 & 0.15 & 0.10 & 0.06 \\
\hline Total expenditure on personal modes & 0.64 & 0.61 & 0.57 & 0.52 \\
\hline Expenditure on cars & 0.75 & 0.70 & 0.65 & 0.58 \\
\hline Expenditure on motorized two-wheelers & 0.37 & 0.38 & 0.37 & 0.35 \\
\hline \multicolumn{5}{|l|}{ Ouagadougou } \\
\hline Total transport expenditure & 0.58 & 0.56 & 0.52 & 0.43 \\
\hline Expenditure on public transport & 0.35 & 0.41 & 0.41 & 0.38 \\
\hline Expenditure on personal modes & 0.59 & 0.57 & 0.53 & 0.44 \\
\hline \multicolumn{5}{|l|}{ Dar es Salaam } \\
\hline Total transport expenditure & 0.57 & 0.56 & 0.53 & 0.48 \\
\hline Expenditure on public transport & 0.41 & 0.40 & 0.37 & 0.32 \\
\hline Expenditure on personal modes & 0.93 & 0.93 & 0.90 & 0.86 \\
\hline
\end{tabular}

Two noteworthy observations with regard to inequalities in the use of means of transport and the respective transport expenses can be drawn from Table 6. The first one is that amongst the three case studies, Niamey has the lowest concentration of total expenditure on transport. This result may be a consequence of a higher degree of coexistence between public and private transport modes in Niamey than in the other two 
case studies. Diversity in urban transport supply could encourage a less unequal distribution of transport expenditure in the city, but such a finding would need to be supported by further research on other African cities.

The second observation is that the concentration indices suggest strong inequalities between households with regard to the use of public and private modes. In Niamey and Dar es Salaam, expenditure on public transport is more evenly distributed throughout the population than expenditure on personal vehicles. The concentration indices for expenditure on personal modes are high in Niamey and particularly in Dar es Salaam because of the disparity between high costs of vehicle purchase and use and the low income of the overwhelming majority of households. Expenditure on personal transport modes is thus concentrated among the very small minority of households that own a car or a motorized two-wheeler. Conversely, in Ouagadougou the distribution of expenditure on personal modes is least unequal while the one on public transport is most unequal in the case of three equivalence scales. This is due to the high ownership rates of motorized two-wheelers and to the fact that public transport expenditure is most concentrated among those with high incomes given that unplanned peripheral areas, where a large number of low-income populations live, are poorly supplied by public transport.

\section{AVERAGE TRANSPORT EXPENDITURE PER PERSON}

Figure 2 illustrates the variation by household quintile of public transport expenditure and personal vehicle expenditure per person (aged 14 and over) according to the selected equivalence scales. Three main results can be drawn. Firstly, with regard to the methodological issue, the sensitivity of results to the equivalence scale is greater for the fifth quintile, the wealthiest, with the exception of public transport expenditure in Niamey, where sensitivity to the equivalence scale is quite insignificant, whatever the quintile. In the other cases, the lowest value for the fifth quintile is given systematically by the total income or expenditure equivalence scale and the highest value by the per capita equivalence scale. For instance, in Dar es Salaam, the total expenditure equivalence scale estimates the average personal vehicle expenditure to Tsh 3,250 (\$8.8) while the per capita expenditure equivalence scale estimates Tsh 5,250 (\$14.2), i.e. an increase of $60 \%$.

Secondly, individual monthly travel expenditure increases with affluence of the household (whatever the equivalence scale, for both items of transport expenditure and for both types of survey data) and in most cases great differences in travel expenditure appear between the first four quintiles and the fifth. This situation is especially marked in the case of personal vehicle expenditure in Dar es Salaam. Lastly, further analysis of values of travel expenditure reveals that whatever the methodological choices (type of survey, case study and equivalence scale), a great number of city dwellers cannot afford 
Figure 2: Sensitivity of average monthly transport expenditure per person of 14 years of age and over to equivalence scales

a- Niamey, public transport PER ADULT EXPENDITURE (FCFA)

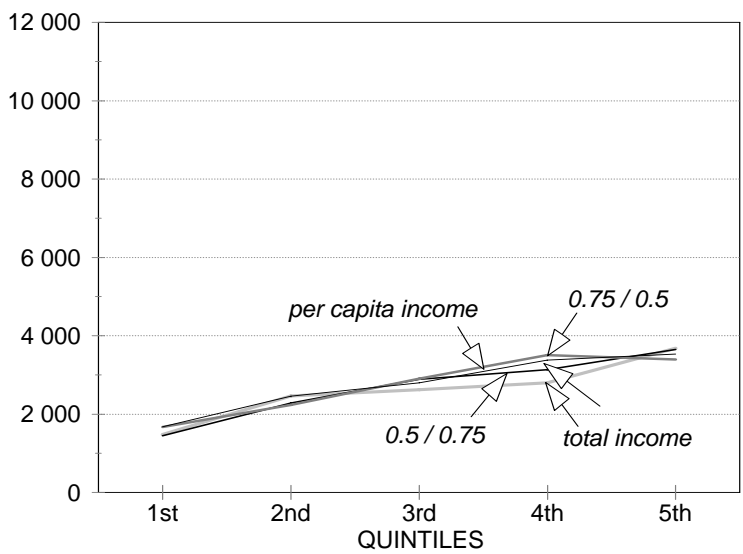

C- Ouagadougou, public transport

PER ADULT EXPENDITURE (FCFA)

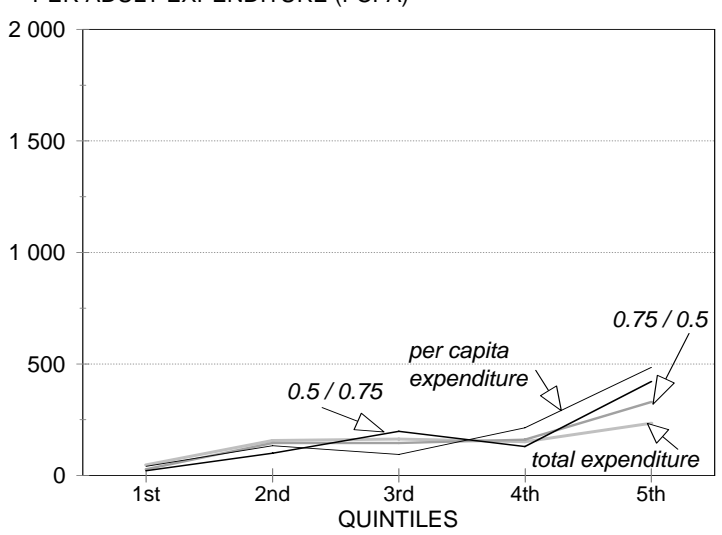

e- Dar es Salaam, public transport PER ADULT EXPENDITURE (TSH)

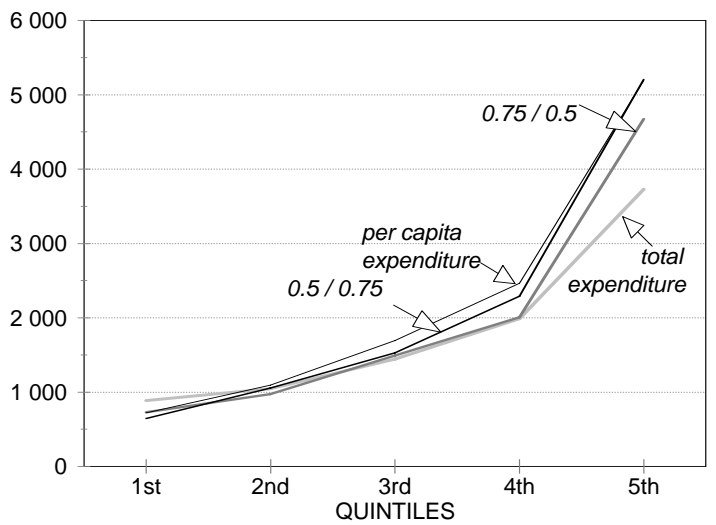

b- Niamey, personal transport PER ADULT EXPENDITURE (FCFA)

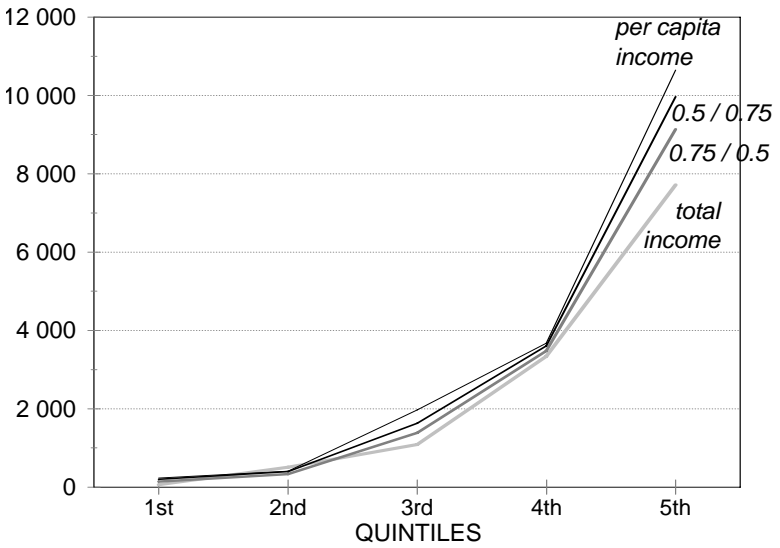

d- Ouagadougou, personal transport PER ADULT EXPENDITURE (FCFA)

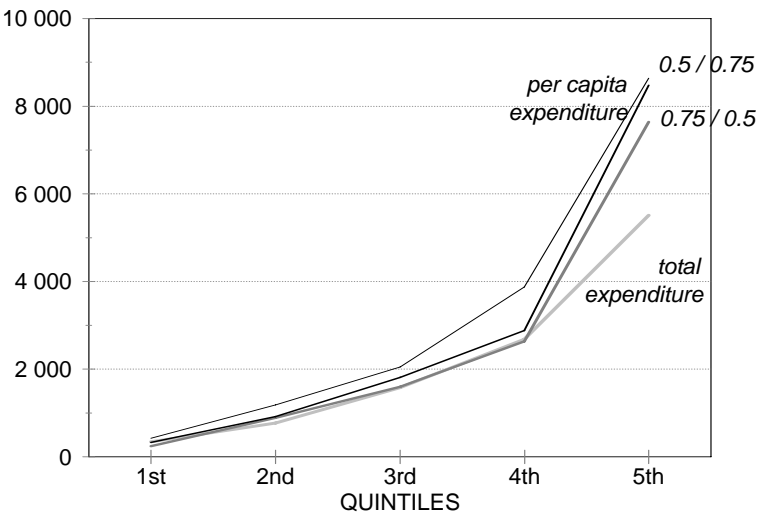

f- Dar es Salaam, personal transport PER ADULT EXPENDITURE (TSH)

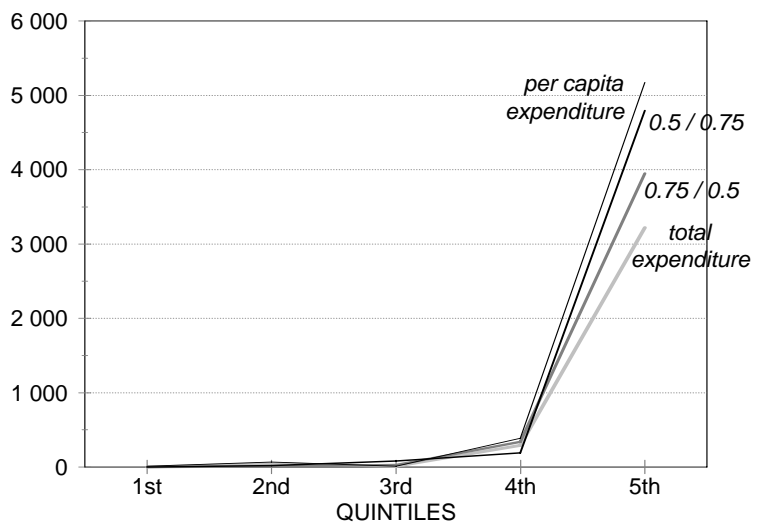

$100 \mathrm{TSh}=$ approximately US\$ 0.27 at the time of the survey. 100 CFA Francs $=$ approximately US\$ 0.10 at the time of the survey. The ordinate scales for both graphs for Niamey and Dar es Salaam are the same. However, different scales have been used for Ouagadougou because of the very low levels of public transport expenditure. 
daily travel in public transport ${ }^{5}$. In Niamey, even though the concentration index (section 6) suggests that use of public transport is less concentrated than in the other two case studies, it is still quite limited. The average expenditure on public transport per person aged of 14 years old and over differs by a factor of around 2 between the two extreme quintiles, irrespective of the equivalence scale (Figure 2a and Table 7).

Table 7: Quintile ratios (Q5/Q1) for monthly public transport expenditure and public transport use in Niamey, according to equivalence scales*

\begin{tabular}{|c|c|c|c|c|}
\hline & \multicolumn{4}{|c|}{ Ratio Q5/Q1 } \\
\hline & $\begin{array}{l}\text { Total } \\
\text { income }\end{array}$ & $\begin{array}{c}\text { Scale } \\
0.75 / 0.50\end{array}$ & $\begin{array}{c}\text { Scale } \\
0.50 / 0.75\end{array}$ & $\begin{array}{l}\text { Per capita } \\
\text { income }\end{array}$ \\
\hline $\begin{array}{l}\text { Average monthly public transport expenditure per } \\
\text { person of } 14 \text { years old and over }\end{array}$ & 2.03 & 2.22 & 1.94 & 2.30 \\
\hline Number of public transport trips on a weekday: & & & & \\
\hline $\begin{array}{l}\text { b: Persons of } 14 \text { years old and over without access } \\
\text { to a personal vehicle }\end{array}$ & $\begin{array}{l}2.04 \\
2.50\end{array}$ & $\begin{array}{l}2.25 \\
2.95\end{array}$ & $\begin{array}{l}1.84 \\
2.55\end{array}$ & $\begin{array}{l}1.8 / \\
2.67\end{array}$ \\
\hline $\begin{array}{l}{ }^{*} \text { Let us consider column } 1 \text {, for example. Public transp } \\
\text { and over for the households ranked in the last total inco } \\
\text { than for the households in the first quintile, the poorest. } \\
\text { belonging to the last quintile make } 2.04 \text { times more publi }\end{array}$ & 1 refe & re per $\mathrm{p}$ & $n$ aged of & $\begin{array}{l}14 \text { years old } \\
\text { times higher } \\
\text { cale, persons } \\
\text { st quintile on } \\
\text { who have no }\end{array}$ \\
\hline
\end{tabular}

This figure is highly consistent with that for the average number of public transport trips made per person on a weekday, i.e., individuals from the wealthiest households travel in public transport twice as much as those from the poorest households. The difference in public transport use between the two extreme quintiles becomes even more pronounced among those with no access to a private car, with ratios of 1 to 2.5 or even 1 to 3 separating the poorest and the wealthiest populations. These figures clearly show that the poorest inhabitants of Niamey cannot afford daily use of public transport: the monthly cost of 20 return trips (i.e. daily usage of shared taxis with no transfer with a fare of 150 CFA Francs - \$0.15) exceeds one sixth of the median salary and amounts to almost one twelfth of median household income.

The differentials between the poorest and the wealthiest households are more obvious in the case of Dar es Salaam. According to the per capita equivalence scale, individuals from households ranked in the last quintile, the wealthiest, spend approximately 5 times more on public transport than those in the poorest quintile (Figure 2e). For the first three quintiles, $80 \%$ of household expenditure is devoted to food and housing. Among the $40 \%$ of households with the lowest total expenditure, once the costs of food and housing have been deducted, the average household has only Tsh 450 (\$1.2) left per day to cover all the other household needs (health, education, transport, other purchases, etc.) and the poorest quintile of households has only Tsh 250 (\$0.7) per day. Given that a round trip

\footnotetext{
${ }^{5}$ Even though fare levels are an essential factor for public transport ridership, the influence of deficiencies in urban transport supply (availability of the service, frequency, etc.) should not be disregarded. In our case studies, this issue was not taken into account due to the unavailability of relevant data.
} 
in daladala cost Tsh $140(\$ 0.4)$ at the time of the survey, it seems clear that the use of public transport is reserved for only the most indispensable trips.

These findings reveal that the estimates of monthly travel expenditure for the individuals from households ranked in the fifth quintile are highly dependent on the equivalence scale used, which may thus considerably modify the measure of inequalities between the most affluent households and the others. Beyond this equivalence scale effect, it should be retained from this analysis that the amount of transport expenditure per person increases continuously with household wealth, irrespective of the equivalence scale and the type of survey data, and that public transport and personal vehicle expenditure raise considerably between the $80 \%$ poorest households and the $20 \%$ better-off households. Monetary well-being is also essential for regular use of public transport and consequently the poorest households are penalized by limited access to overall motorized transport.

\section{CONCLUSION}

The literature review on household travel expenditure in Sub-Saharan African cities shows the gaps in the available data, both with regard to explaining the differences between cities and to rigorous temporal monitoring. Cross-city comparisons reveal that beyond the specific features of each city, particularly those concerning the passenger transport sector, methodological differences in the production and analysis of data partly determine the levels of transport expenditure.

With regard to data production, the type of survey is a key factor. The approach based on household consumption provides a more comprehensive picture of household expenditure and makes it easier to see how respondents make trade-offs between travel expenditure and expenditure on other items, but it probably underestimates the first of these. In contrast, the data from travel surveys may overestimate travel expenditure, when collected on a frequency basis. The data, however, have the major advantage that it can be compared with household vehicle ownership and the daily travel practices of household members.

The literature survey and the case studies showed evidence of the major difference in travel expenditure findings between the two types of sources: the travel survey data (Niamey) suggest that the proportion of expenditure spent on transport decreases as household income increases, while the use of consumption survey data (Dar es Salaam and Ouagadougou) indicates the opposite trend. In order to advance in this area we need to be able to compare both types of survey for the same city and the same year, at all stages from data production to analysis of the results. So far this has not been possible.

Additional information on the specifics of daily travel expenditure and household vehicles would certainly be relevant in travel expenditure analyses. In future, data collection could be made more reliable in a number of ways, without making the carrying out of surveys too complex and costly. For travel surveys:

a. information about the type and frequency of transport expenditure should be more precise, for example which public transport mode was used or, in the case of private vehicles, the type of any maintenance or repair performed; 
b. information about the actual amount spent on each public transport trip made on the previous day would make it possible to make detailed comparisons between travel behavior, real expenditure on a specific means of transport and the reported expenditure over a longer period (a week, for example);

c. details about vehicle purchase strategies (date, price, new or secondhand, etc.) should also be collected, even though information about the vehicle's service life and use would also be required in order to make proper use of this information.

Likewise, in the case of consumption surveys:

a. transport items should be distinguished from other items such as communication;

b. details of the vehicles owned by the household (cars, motorized two-wheelers and bicycles) should systematically be collected and processed as this is a component of the household's wealth;

c. it would also be relevant to identify what access the different members of the household have to the vehicles, as well as each adult's real expenditure on personal and public transport, in order to minimize the risk that this expenditure will be omitted. This additional information would, however, require a major change in consumption survey data collection methods.

Beyond the variations due to methodological factors, the sensitivity tests in the three case studies highlight three facts: there are considerable structural inequalities between households, transport is a major component of poor household expenditure and daily use of public transport is unaffordable for the poor populations. These barriers to the use of motorized transport have significant consequences on the economic and social development of Sub-Saharan African cities. The high cost of public transport travel reinforces the tendency to remain in one's own district, as an individual survival strategy to face economic crisis, and therefore increases the vulnerability of the poor by hindering their building up of labor, human and social capital assets. This is particularly the case in unplanned peripheral districts where the level of basic service provision and the number of jobs available locally are far from equaling those in central or peri-central districts. In these ever-expanding areas, even though low-resource households limit motorized travel to the most essential trips, travelling by public transport imposes additional pressure on their budgets.

Even though the findings of this study clearly state that poor households cannot afford daily public transport ridership, estimations of transport expenditure are still too rough. They do not allow the thorough identification of groups of population being deprived from regular public transport use because of its unaffordability and therefore they also hinder the decision-makers' capability to target these populations in the formulation of transport policies. In order to take the transport sector into consideration in the pro-poor urban development policies there is an urgent need for better knowledge of how much daily travel costs in Sub-Saharan African cities and what it implies for the household budget. 


\section{REFERENCES}

Akinlo, E. A., 1998. Improved urban transport as a strategy for reducing poverty. In: Freeman, P., Jamet, Ch. (Eds.), Urban transport policy: a sustainable development tool. Proceedings of the International Conference CODATU VIII. Balkema, Rotterdam, pp. 705-708.

Arnaud, M., 1998. Dynamique de l'urbanisation de l'Afrique au sud du Sahara. ISTED-Ministère des Affaires Etrangères-Coopération et Francophonie, Paris.

Arulpragasam, J., del Ninno, C., 1993. Price changes and their effect on consumption in Conakry. Policy implications from an estimation of demand. Encomec Findings: Bulletin $n^{\circ} 12$, Ministère Guinéen de la Santé et des Affaires Sociales-Cornell Food and Nutrition Policy Program, Conakry.

Banque Mondiale, 1996. Évaluation de la pauvreté au Gabon. Division Population et Ressources Humaines, Région Afrique, Washington, D.C.

Behrens, R., Diaz Olvera, L., Plat, D., Pochet, P., 2004. Meta-analysis of travel of the poor in West and Southern African cities. In: 10th World Conference on Transport Research, July 4-8, Istambul.

Blaizeau, D., 1999. Sept enquêtes sur les dépenses des ménages dans les pays de l'UEMOA. In : Colloque Francophone sur les Enquêtes et Systèmes d’Information, April 27-30, Abidjan.

Blaizeau, D., Dubois, J.-L., 1989. Connaître les conditions de vie des ménages dans les pays en développement. Tome II Collecter les informations. Ministère de la Coopération et du Développement, Paris.

Button, K., Ngoe, N., Hine, J., 1993. Modelling Vehicle Ownership and Use in Low Income Countries. Journal of Transport Economics and Policy 27 (1), 51-67.

Canagarajah, S., Ngwafon, J., Thomas, S., 1996. The evolution of poverty and welfare in Nigeria (198592). Population and Human Resources Division, West Central Africa Department, World Bank, Washington, D.C.

Case, A., Deaton, A., 2002. Consumption, health, gender and poverty. Research Program in Development Studies, Princeton University.

(www.worldbank.org/gender/promising/casedeatonjuly2002.pdf).

CBS, HRSSD, 2000a. Second report on poverty in Kenya. Vol. I. Incidence and depth of poverty. Studies in Employment and Rural Development $n^{\circ} 55$, Ministry of Finance and Planning, Nairobi.

CBS, HRSSD, 2000b. Second report on poverty in Kenya. Vol. II. Poverty and social indicators. Studies in Employment and Rural Development $n^{\circ} 55$, Ministry of Finance and Planning, Nairobi.

de Suremain, Ch.-E., 1997. Itinéraires de la "souffrance” quotidienne. Sur les pratiques et les stratégies alimentaires des familles brazzavilloises face à la crise. In: Atelier ORSTOM-CEDERS Ménages et Crise, March 24-26, Marseille, France.

Dargay, J., Gately, D., 1999. Income’s effect on car and vehicle ownership, worldwide: 1960-2015. Transportation Research Part A 33 (2), 101-138.

Deaton, A., 1997. The analysis of household surveys. Johns Hopkins University Press, Baltimore.

Deaton, A., Grosh, M., 2001. Consumption. In: Grosh, M., Glewwe, P. (Eds.), Designing household survey questionnaires for developing countries: lessons from ten years of LSMS experience. Oxford University Press, Oxford, pp. 91-133.

Deaton, A., Paxson, Ch., 1997. Poverty among children and the elderly in developing countries. Working Paper $n^{\circ}$ 179, Woodrow Wilson School of Public and International Affairs, Princeton University. (http://www.wws.princeton.edu/ rpds/agepov1.pdf).

Deaton, A., Zaidi, S., 1999. Guidelines for constructing consumption aggregates for welfare analysis. Working Paper $n^{\circ}$ 192, Woodrow Wilson School of Public and International Affairs, Princeton University. (http://www.wws.princeton.edu/ rpds/deatonzaidi.pdf).

DIAL, DSCN, 1993. Consommation et conditions de vie des ménages à Yaoundé. Premiers résultats Enquête 1-2-3, phase 3. Paris.

Diaz Olvera, L., Plat, D., Pochet, P., 1999. Mobilité quotidienne des citadins à faibles ressources. Les enseignements de Ouagadougou. Revue Tiers-Monde, XL (160), 829-848. 
Diaz Olvera, L., Plat, D., Pochet, P., 2001. Dépenses de transport des ménages en Afrique subsaharienne. Méthodes et mesures appliquées au cas de Niamey. Recherche Transport Sécurité 72, 19-32 (short version in English: 33-36).

Diaz Olvera, L., Plat, D., Pochet, P., Cusset, J.-M., 1998. Vers une ville à deux vitesses ? Transport et accès aux équipements à Dar es Salaam. Laboratoire d’Économie des Transports, Lyon.

Direction de la Statistique et de l'Informatique, 1988. Enquête sur la consommation de produits essentiels à Niamey, Décembre 1986-Janvier 1987. Ministère du Plan, Niamey.

Direction de la Statistique, 1986. Enquête budget consommation 1979. Les déplacements des personnes en Côte d'Ivoire. Ministère du Plan, Abidjan.

DSCN, 1994. Enquête sur le budget et la consommation des ménages au Niger, "Phase urbaine” 19891990, Volet A: les dépenses, la consommation et l'approche de la pauvreté en milieu urbain. Ministère des Finances et du Plan, Niamey.

DSCN, 1997. Enquête permanente de conjoncture économique et sociale 1994: Rapport d'analyse. Ministère du Plan-PNUD, Niamey.

Dubresson, A., 1996. Crise(s) et peuplement des villes en Afrique au sud du Sahara. In: Coussy, J., Vallin, J. (Eds.), Crise et population en Afrique. Crises économiques, politiques d'ajustement et dynamiques démographiques. Études du CEPED n 13, CEPED, Paris, 375-405.

Duclos, J.-Y., Mercader-Prats, M., 1999. Household needs poverty: with application to Spain and the UK. Review of Income and Wealth, 45 (1), 77-98.

Ekström, E., 1998. Income distribution and labour market discrimination: a case study of Namibia. IUI Working paper Series $n^{\circ}$ 502, Research Institute of Industrial Economics, Stockholm.

Gannon, C. A., Liu, Z., 1997. Poverty and transport. TWU Papers n ³0, World Bank, Washington, D.C.

Garau, P., 1989. Third World cities in a global society viewed from a developing nation. In: Knight, R. V., Gappert, G. (Eds.), Cities in a global society. Sage, London.

Godard, X., Teurnier, P., 1992. Les transports urbains en Afrique à l'heure de l'ajustement. Redéfinir le service public. Karthala, Paris.

Grieco, M., Apt, N., Turner, J., 1996. At Christmas and on rainy days. Avebury, Hampshire.

Grootaert, Ch., 1993. The evolution of welfare and poverty under structural change and economic recession in Côte d'Ivoire, 1985-88. Policy Research Working Papers Series 1078, World Bank, Washington, D.C.

Houyoux, J., Niwembo, K., Onya, O., 1986. Budgets des ménages, Kinshasa 1986. BEAU-ICHEC, Kinshasa.

INSAE, 1994. La pauvreté au Bénin à travers les résultats de l'enquête budget consommation de 19861987, EBC Vol. 13. Ministère du Plan et de la Restructuration Économique, Cotonou.

INSD, 1999. Analyse des résultats: résultats pour l'ensemble des États de l’UEMOA. In: Projet d'harmonisation des indices de prix dans les pays de l'UEMOA, Enquête sur les Dépenses des Ménages de Ouagadougou 1996. Ministère de l’Économie et des Finances, Ouagadougou.

INSEE, 1997. Enquête Budget des Familles 1995. Vol. 1 Base sur les dépenses. INSEE, Paris.

Jaglin, S., 1995. Gestion urbaine partagée à Ouagadougou. Pouvoirs et périphéries (1983-1991). Karthala, Paris.

Kinda, F., 1987. Ménages populaires à Ouagadougou. Thèse de Doctorat en Sociologie, Université de Nantes, France.

Kourguéni, I. A., Garba, B., Barrère, B., 1993. Enquête démographique et de Santé Niger 1992. Ministère des Finances et du Plan - Macro International Inc, Niamey.

Kranton, R. E., 1991. Transport and the mobility needs of the urban poor: en exploratory study. INU-86, Infrastructure and Urban Development Department, World Bank, Washington, D.C.

Kwakye, E. A., Fouracre, P.-R., Ofusu-Dorte, D., 1997. Developing strategies to meet transport needs of the urban poor in Ghana. World Transport Policy and Practice 3 (1), 8-14.

Lachaud, J.-P., 2000. Échelles d’équivalence et différentiel spatial de pauvreté et d’inégalité au Burkina Faso. Documents de Travail n 46, Centre d’Économie du Développement, Bordeaux, France. 
Lancaster, G., Ray, R., Valenzuela, R., 1999. A cross country study of equivalence scales and expenditure inequality on unit record household budget data. Review of Income and Wealth 45 (4), 455-482.

Lechêne, V., 1993. Une revue de la littérature sur les échelles d’équivalence. Économie et Prévision 110111, 169-182.

Leimdorfer, F., 1997. Individus entre famille et entreprise: patrons et patronnes de restaurants populaires à Abidjan. In: Marie, A. (Ed.), L’Afrique des individus. Karthala, Paris, 113-169.

Lynch, S. G., 1991. Income distribution, poverty and consumer preferences in Cameroon. Ithaca University, Ithaca.

Marie, A., 1997. Individualisation: entre communauté et société l’avènement du sujet. In Marie, A. (Ed.), L’Afrique des individus. Karthala, Paris, 407-436.

Mattila-Wiro, P., 1999. Economic theories of the household: a critical review. Working Paper $n^{\circ} 159$, WIDER, Helsinki.

Maunder, D. A. C., Fouracre, Ph. R., 1987. Public transport provision in Dar es Salaam, Tanzania. Working paper $n^{\circ} 231$, Transport and Road Research Laboratory, Crowthorne.

Michaud, D., 1964. Les budgets familiaux africains à Niamey 1961-1962. Service de Coopération, INSEE, Paris.

Ministère de l’Économie et des Finances, 2001. Enquête sur les dépenses des ménages à Douala et à Yaoundé (EDM 2000). Données sur la consommation finale des ménages. Direction de la Statistique et de la Comptabilité Nationale, Yaoundé.

Ministère de l’Économie, des Finances et du Plan, 1997. Enquête sénégalaise auprès des ménages (ESAM), rapport de synthèse. Direction de la Statistique, Dakar.

Muller, Ch., 1997. Transient seasonal and chronic poverty of peasants: evidence from Rwanda. Working Paper Series n ${ }^{\circ}$ 97-8, Centre for the Study of African Economies, Oxford.

(www.economics.ox.ac.uk/CSAEadmin/workingpapers/pdfs/9708text.pdf).

Ngabmen, H., 1997. Crise des transports collectifs urbains et stratégies d'adaptation: le cas de Yaoundé. In: Figueroa, O., Godard, X., Henry, E. (Eds.), Mobilité et politiques de transport dans les villes en développement. Actes $n^{\circ}$ 55, INRETS, Arcueil, France.

Ngassam, A., Roubaud, F., 1994. Cameroun, un profil de pauvreté. DSCN-DIAL, Paris.

Osula, D. O. A., 1999. Public transport fare subsidies for children and the elderly in developing countries. In: Sixth International Conference on Competition and Ownership in Land Passenger Transport, September 19-23, Cape Town.

Osula, D. O. A., Adebisi, O., 2001. Testing the stability of travel expenditures in Nigeria. Transportation Research Part A 33 (2), 269-287.

Pochet, P., Cusset, J.-M., 1999. Cultural barriers to bicycle use in West African cities. The case of Bamako and Ouagadougou. IATSS Research 23 (2), 43-50.

Porter, G., 2002. Living in a walking world: rural mobility and social equity issues in Sub-Saharan Africa. World Development 30 (2), 285-300.

Quisumbing, A. R., Haddad, L., Peña, Ch., 1995. Gender and poverty: new evidence from 10 developing countries. FCND Discussion Paper $n{ }^{\circ}$ 9, International Food Policy Research Institute, Washington, D.C. (www.ifpri.cgiar.org/divs/fcnd/dp/papers/dp09.pdf).

Rone, B. N., 1995. Le profil de pauvreté à N’Djamena. Direction de la Statistique, des Études Économiques et Démographiques, N’Djamena.

Sanogo, B., 1993. Activités et revenus des ménages. In: ENSUP (Ed.), Bamako. Pays Enclavés nº 6, CRET-Université de Bordeaux, France.

Sitrass, 2004a. Poverty and Urban Mobility in Conakry, Final Report. Sub-Saharan Africa Transport Policy Program, SSATP Report No 09/04/CKR, World Bank, Washington, D.C. (http://www4.worldbank.org/afr/ssatp/Resources/PapersNotes/Conakry_en.pdf)

Sitrass, 2004b. Poverty and Urban Mobility in Douala, Final Report. Sub-Saharan Africa Transport Policy Program, SSATP Report No 09/04/Dla, World Bank, Washington, D.C. (http://www4.worldbank.org/afr/ssatp/Resources/PapersNotes/Douala_en.pdf) 
Uganda Bureau of Statistics, 2001. Uganda national household survey 1999-2000, report on the socioeconomic. Uganda Bureau of Statistics, Entebbe.

Vasconcellos, E. A., 2001. Urban transport, environment and equity. The case for developing countries. Earthscan, London.

World Bank, 1994. Zambia poverty assessment. Vol. IV: urban sector services, an assessment of service provision in the context of Zambia's urban poverty. Report $n^{\circ} 12985-Z A$, Africa Regional Office, World Bank, Washington, D.C.

Yapi-Diahou, A., 2000. Baraques et pouvoirs dans l'agglomération abidjanaise. L'Harmattan, Paris. 